\title{
Internasionalisasi Kota: Gorontalo, Berkearifan Lokal Berwawasan Global
}

\author{
Atika Marzaman \\ Program Studi Ilmu Pemerintahan, Universitas Gorontalo \\ tika.marzaman@gmail.com
}

\begin{abstract}
The open access to information and the rapid turnover of goods and services encourages the city to emerge as one of the actors in international relations. Not only that, cities in different parts of the world can compete instantly without any obstacles. The current phenomenon is that cities interact directly, establishing cooperative relationships in commerce, government, education, as well as in peace building missions.

This research is trying to study Gorontalo's potential to become an international region with the development of global cooperation. This research is done by qulitative method through interview and literature source search. With the potential and a very strategic location Gorontalo has a great opportunity to cooperate with other regions in various parts of the world. This study try to assess Gorontalo's capacity to internationalize itself. Using the data obtained this research analyze the opportunities and challenges faced in the internationalization process of Gorontalo City.

The results show that regionalization through an international cooperative model actually offers a bright prospect. However, institutional obstacles need to be responded by local and central government through strengthening the leadership and capacity of the government, providing clear rules of law, supervision in policy implementation and adequate funding.
\end{abstract}

Keywords: city internalization; Gorontalo.

Akses informasi yang terbuka dan perputaran barang dan jasa yang cepat mendorong kota untuk muncul sebagai salah satu aktor dalam hubungan internasional. Tidak hanya itu, kota-kota di berbagai belahan dunia dapat berkompetisi secara instan tanpa hambatan. Fenomena saat ini adalah bahwa kota berinteraksi secara langsung, membangun hubungan kerja sama dalam perdagangan, pemerintahan, pendidikan, serta dalam misi pembangunan perdamaian.

Penelitian ini mencoba mengkaji potensi Gorontalo untuk menjadi kawasan internasional dengan pengembangan kerjasama global. Penelitian ini dilakukan dengan metode qulitatif melalui wawancara dan penelusuran sumber pustaka. Dengan potensi dan lokasi yang sangat strategis Gorontalo memiliki peluang besar untuk bekerja sama dengan daerah lain di berbagai belahan dunia. Studi ini mencoba menilai kapasitas Gorontalo untuk menginternasionalkan dirinya sendiri. Dengan menggunakan data yang diperoleh penelitian ini menganalisis peluang dan tantangan yang dihadapi dalam proses internasionalisasi Kota Gorontalo.

Hasilnya menunjukkan bahwa regionalisasi melalui model koperasi internasional sebenarnya menawarkan prospek yang cerah. Namun, hambatan kelembagaan perlu ditanggapi oleh pemerintah lokal dan pusat melalui penguatan kepemimpinan dan kapasitas pemerintah, memberikan aturan hukum yang jelas, pengawasan dalam implementasi kebijakan dan pendanaan yang memadai.

Kata Kunci: internasionalisasi; Gorontalo. 


\section{PENDAHULUAN}

Globalisasi telah menciptakan dunia yang tampa hambatan dan saling terkoneksi. Negara atau pemerintah tidak lagi dianggap sebagai aktor tunggal dalam hubungan internasional (Government to Government). Semakin dinamisnya konstelasi internasional juga semakin melibatkan aktor-aktor nonnegara. Perusahaan multinasional, salah satunya, telah mampu memjadi bagian penting dalam interaksi internasional. Bahkan lebih dari itu, interaksi global juga saat ini sudah diisi dengan hubungan langsung antar manusia (people to people).

Adapun fenomena yang terjadi saat ini adalah aktor-aktor lokal dapat ikut mengambil bagian dalam interaksi global. Kota hadir sebagai pemain baru dalam hubungan internasional. Jika dulunya setiap interaksi internasional harus mengandalkan pemerintah pusat, maka hal yang sangat berbeda terjadi pada era globalisasi saat ini. Kota kini mampu melakukan hubungan langsung dengan daerah maupun manusia yang berada dalam lingkup ototitas negara yang berbeda.

Keterbukaan atas akses informasi dan perputaran barang dan jasa yang sangat cepat mendorong kota untuk mampu tampil sebagai salah satu aktor dalam hubungan internasional. Tidak hanya itu, kota-kota di belahan dunia yang berbeda kini dapat bersaing dan berkompetisi secara langsung tanpa adanya hambatan. Fenomena yang ada saat in adalah kota-kota berinteraksi secara langsung, melakukan hubungan kerjasama baik dalam perdagangan, pemerintahan maupun dalam misi penciptaan perdamaian.

Tidak dapat dipungkiri bahwa kehadiran kota-kota besar di dunia telah banyak berpengaruh dalam hubungan kerjasama global. Beberapa contoh diantaranya adalah Kota Madrid di Spanyol, Kota Miami di Amerika Serikat, dan Cape Town di Afrika Selatan. Beberapa kota ini telah tumbuh menjadi kota internasional yang saat ini telah mampu mengakses dan melakukan kerjaama secara global. Madrid contohnya, merupakan salah satu kota yang sangat aktif mempromosikan internasionalisasi. Hal ini terlihat dari rancangan internasionalisasi Kota Madrid (Madrid Internasonaalisation Plan 2008-2011). Saat ini kota Madrid telah menjadi kota metropolitan terbesar ketiga di Uni Eropa. Ekspansinya ke dunia internasional telah mampu mendorong percepatan pembangunan yang sangat pesat terutama dalam hal perekonomian.

Sebagai salah satu kota yang sedang tumbuh, internasionalisasi merupakan konsep yang tidak begitu lazim bagi kota Gorontalo. Jika melihat sejarahnya, Gorontalo merupakan salah satu Provinsi di kawasan timur Indonesia yang melepaskan diri dari Provinsi Sulawesi Utara, kemudian menjadi provinsi Gorontalo yang berdiri sendiri. Untuk itu sebagai daerah yang baru saja melepaskan diri maka Gorontalo masih harus melakukan akselerasi baik dalam hal pembangunan terutama dalam pembangunan kerjasama.

Provinsi Gorontalo adalah salah satu dari 32 provinsi di wilayah Republik Indonesia yang memanjang dari Timur ke Barat di Bagian Utara Pulau Sulawesi. Sebelah Utara berbatasan dengan Laut Sulawesi, Sebelah Timur berbatasan dengan Provinsi Sulawesi Utara, Sebelah Barat berbatasan dengan Provinsi Sulawesi Tengah, Sebelah Selatan berbatasan dengan Teluk Tomini. Wilayah Gorontalo juga sangat strategis bila dipandang secara ekonomis, karena berada pada poros tengah wilayah pertumbuhan ekonomi, yaitu antara 2 (dua) Kawasan Ekonomi Terpadu (KAPET) Batui Provinsi Sulawesi Tengah dan Manado - Bitung 
Provinsi Sulawesi Utara. Letaknya yang strategis ini dapat dijadikan sebagai daerah transit seluruh komoditi dari dan menuju kedua KAPET tersebut. Akibat kegiatan arus barang antara kedua KAPET tadi, maka berdampak positif terhadap peningkatan aktivitas ekonomi di Daerah Sulawesi Utara, Sulawesi Tengah dan bahkan Sulawesi Tenggara dan Sulawesi Selatan. Selain itu, Gorontalo juga berada pada "mulut" Lautan Pasifik yang menghadap pada negara Korea, Jepang dan Amerika Latin. Sudah barang tentu "kelebihan posisi" ini dapat memberikan peluang yang baik dalam pengembangan perdaganga

Jika dilihat dari potensi daerah, maka pertanian merupakan modal utama dari Provinsi Gorontalo. Beberapa tanaman padi dan palawija yang banyak dibudidayakan di Provinsi Gorontalo meliputi padi sawah, jagung, ubi kayu, ubi jalar, kacang kedelai, kacang hijau, dan kacang tanah. Luas panen padi (sawah dan ladang) tahun 2011 adalah 52.811 hektar dengan luas panen terbesar berada di Kabupaten Gorontalo seluas 23.238 hektar. Sementara luas panen jagung di Provinsi Gorontalo adalah seluas 135.754 hektar. Untuk luas panen jagung terbesar berada di Kabupaten Pohuwato dengan 47 persen dari total luas panen jagung provinsi (Gorontalo Prov).

Dengan adanya potensi dan lokasi yang sangat strategis yang dimiliki maka menjadi peluang yang sangat besar bagi Gorontalo untuk melakukan hubungan kerjasama dengan wilayah lain di berbagai belahan dunia. Untuk ini penelitian ini akan mencoba untuk mengkaji kapasitas Gorontalo untuk menginternasionalisasi dirinya. Dengan menggunakan sudut pandang konstruktivis penelitian ini akan mencoba mengaitkan antara aspek ide dan budaya dengan proses internasionalisasi Kota Gorontalo.

\section{STUDI PUSTAKA}

\subsection{Internasionalisasi Kota}

Teori interasionalisasi merupakan bukan teori yang baru. Teori ini telah mulai diperkenalkan seiring dengan semakin intensifnya interaksi internasional. Telah dijelaskan sebelumnya bahwa saat ini hubungaan internasional tidak lagi didominasi oleh negara sebagai aktor utama. Kota telah menjadi aktor penting dalam interaksi global.

Ada beberapa alasan mengapa kota memilih untuk telibat langsung dalam hubungan internasional, antara lain:

a. Globalisasi. Dunia yang tanpa batas telah mendoro kota untuk telibat secara langsung dalam persaingan global. Akses terhadap informasi yang semakin terbuka didukung dengan komunikasi dan transportasi yang semakin cepat mendorong kota untuk maju menjadi aktor yang tidak lagi harus membawa identitas negara.

b. Perdagangan Internasional. Mampu melakukan hubungan dagang secara langsung dengan negara lain tentunya sangat menggiurkan bagi suatu daerahdimana peredaran arus barang dan jasa yang semakin cepat.

c. Kerjasama Antar-Pemerintah. Disamping keinginan untuk memperoleh keuntungan secara ekonomis, salah satu pendorong suatu daerah melalukan interaksi internasional adalah untuk melakukan kerjasama dalam hal pemerintahan. Kerjasama ini tentunya akan memberikan dampak positif bagi pengembangan kota. 
Adapun beberapa strategi yang diterapkan dalam proses internasionalisasi kota adalah :

a. Konektivitas. Interkoneksi merupakan syarat utama yang harus dipenuhi oleh suatu kota yang akan menginternasionalisasi dirinya. Suatu kota yang mampu bersaing di tingkat internasional harus memiliki koneksi yang memadai baik dalam hal komunikasi maupun transportasi.

b. Infrastruktur. Tersedianya infrastruktur yang baik menjadi kebutuhan dari kemajuan suatu daerah. Perputaran arus barang dan jasa baru dapat berjalan dengan maksimal jika didukung oleh infrastruktur yang baik. Untuk itu dalam rangka mencapai suatu predikat kota internasional, hal utama yang harus disediakan adalah infrastruktur guna menunjang proses perdagangan dan perpindahan manusia.

c. Budaya Ramah Tamah. Budaya merupakan salah satu nilai tambah bagi suatu daerah. Budaya yang baik akan memberikan image yang baik bagi suatu daerah. Dalam rangka menciptakan kota internasional, suatu daerah tentunya harus menyediakan bentuk-bentuk kebudayaan yang mampu menarik bagi dunia intenasional.

d. Identitas, Nilai dan Karakter. Pembangunan karakter dan branding suatu daerah menjadi keharusan dalam rangka inetrnasionalisasi. Hal ini untuk memberikan ciri khas bagi daerah yang akan membedakan dengan daerah lainnya. CityBranding juga dengan sendirinya akan menaikkan pamor suatu daerah sehingga memudahkannya untuk merebut pasar dalam persaingan global.

\subsection{Kerjasama Internasional}

Kerjasama internasional dapat terselenggara berkat adanya kesamaan visi dan keselarasan kepentingan diantara aktor-aktor yang berinteraksi. Melalui kerjasama internasional, suatu pihak mengharapkan kepentingannya akan lebih mudah diwujudkan daripada berusaha sendiri.

Kerjasama internasional bukan saja dilakukan antar negara secara individual, tetapi juga dilakukan antarnegara yang bernaung dalam organisasi atau lembaga internasional. Kerjasama internasional terbentuk karena kehidupan internasional meliputi berbagai bidang, seperti ideologi, politik, ekonomi, sosial budaya, lingkungan hidup, pertahanan dan keamanan. Berbagai masalah tersebut maka beberapa negara membentuk suatu kerjasama internasional. Lingkup aktivitas yang dilaksanakan melalui kerjasama internasional antar negara meliputi berbagai kerjasama multidimensi, seperti kerjasama ekonomi, kerjasama dalam bidang sosial, dan kerjasama dalam bidang politik.

\section{METODE PENELITIAN}

Penelitian yang bertujuan untuk mengetahui proses internasionalisasi Kota Gorontalo iniakandilakukan dengan metode kualitatif. Pengumpulan data melalui metode kualitatif dilakukan melalui melakukan wawancara mendalam (depth interview) yang melibatkan masyarakat, akademisi universitas lokal, serta pengambil kebijakan. Kegiatan wawancara ini dimaksudkan untuk menjadi sumber utama dalam mengatahui sejauh mana Kota Gorontalo mampu berkembang menjadi kota internasional.Pengumpulan data melalui wawancara diharapkan akan mampu memberikan infomasi yang akurat mengenai 
pengembangan Kota Gorontalo dan implikasinya dalam kaitannya dengan peningkatan hubungan kerjasama internasional baik dalam hal perdagangan, pemerintahan, pendidikan, maupun penciptaan perdamaian.

Di samping melakukan wawancara, penelitian juga akan menggali data dari dokumen-dokumen dan penerbitan resmi yang dikeluarkan oleh pemerintah pusat maupun daerah baik berupa data statistik (daerah dalam angka), kebijakan (peraturan pemerintah pusat dan daerah), maupun dokumen yang dikeluarkan oleh asosiasi pelaku bisnis atau LSM terkait.

\section{HASIL PENELITIAN}

Saat ini telah tumbuh kesadaran pentingya kerjasama antar daerah di Indonesia. Beberapa pemerintahan daerah secara intensif bekerja sama untuk mengatasi berbagai persoalan dan isu lintas yurisdiksi mereka. Fenomena kerjasama antar daerah bahkan antar daerah antar negara tersebut mengindikasikan telah terjadi perubahan paradigma birokrasi tradisional - yang menekankan piramida kontrol dan maksimalisasi spesialisasi kerja - menuju post-bureaucracy yang mendorong terbentuknya model-model transaksi baru berdasarkan kebutuhan pasar serta menggantikan pengawasan eksternal.

Dalam kerangka otonomi daerah, kerjasama antar daerah antar negara dimaksudkan untuk meningkatkan daya saing daerah tidak saja di level nasional tetapi juga di level internasional melalui pemanfatan lingkungan strategi untuk melakukan pertukaran informasi, sumber daya, keahlian, dan teknologi. Secara normatif, kerjasama antar daerah antar negara juga telah difasilitasi oleh Peraturan Menteri Dalam Negeri No. 3 tahun 2008 tentang Pedoman Pelaksanaan Kerjasama Pemerintah Daerah dengan Pihak Luar Negeri (Bab III Pasal 3). Ketentuan normatif tersebut mengatur bentuk-bentuk kerjasama sebagai berikut:

1. Kerjasama provinsi dan kabupaten / kota "kembar",

2. Kerjasama teknik termasuk bantuan kemanusiaan,

3. Kerjasama penyertaan modal, dan

4. Kerjasama lain sesuai dengan peraturan perundangan

Dengan adanya panduan kerjasama tersebut maka setiap daerah mampu untuk menyusun suatu kerangka kerjasama sehingga diharapkan akan dapat lebih meningkatkan kapasitas daerah baik dalam hal perekonomian, politik maupun sosial budaya. Beberapa daerah di Indonesia yang telah melakukan kerjasama internasional pada kenyataannya telah mampu untuk berkembang lebih maju.

Gorontalo sebagai salah satu daerah yang baru berkembang tentunya wajib memberikan perhatian penting pada bentuk-bentuk kerjasama internasional. Pemerintah tentunya harus menyiapkan perangkat baik itu dalam hal peraturan daerah dan menyiapkan infrastruktur untuk mengundang investasi internasional dalam rangka pembangunan Gorontalo. Adapun beberapa keunggulan Provinsi Gorontalo yang dapat menjadi modal utama dalam menjalin kerjasama internasional dijelaskan sebagai berikut.

\subsection{Memiliki Komoditas Unggulan di Bidang Pertanian}

Teori kerjasama internasional menjelaskan bahwa kerjasama internasional dapat terselenggara berkat adanya kesamaan visi dan keselarasan kepentingan diantara aktor-aktor yang berinteraksi. Melalui kerjasama internasional, suatu 
pihak mengharapkan kepentingannya akan lebih mudah diwujudkan daripada berusaha sendiri.

Di provinsi Gorontalo sendiri dalam mencapai target pertama dalam kriteria ekonomi yang sehat, pemerintah provinsi Gorontalo mencanangkan program Agropolitan berbasiskan komoditi jagung, yang dianggap nantinya menjadi lokomotif pembangunan ekonomi secara berkelanjutan. Hal ini juga tidak lain adalah untuk mencapai tujuan ekonomi yang hakiki yaitu menuju kepada ketahanan pangan secara berkelanjutan. Dalam perjalanannya pembangunan pertanian melalui program agropolitan berbasiskan komoditi jagung telah membawa dampak yang sangat signifikan bagi pembangunan ekonomi di Provinsi Gorontalo, hal ini ditandai dengan meningkatnya angka pertumbuhan ekonomi setiap tahunnya melebihi angka rata-rata nasional.

Provinsi Gorontalo sendiri mempunyai beberapa strategi pembangunan pertanian. Untuk mewujudkan pembangunan pertanian di Provinsi Gorontalo, dikenal 9 faktor yang merupakan 9 pilar strategi pelaksanaan pembangunan ekonomi melalui program agropolitan. Ke 9 pilar ini telah dilakukan bersamasama oleh seluruh stakeholder yang ada, juga telah ditetapkan sebagai indikator pertanian modern yang akan dicapai. Adapun sembilan pilar tersebut adalah sebagai berikut;

a. Pengembangan dan Penyediaan Alat dan Mesin Pertanian serta Angkutan Agropolitan.

b. Menyediaan dana penjaminan petani (APBN + APBD + ASKRINDO + Bank BRI +Bank Mandiri + Bank BNI).

c. Penyediaan benih / bibit unggul, pupuk dan pengendalian hama penyakit.

d. Memperlancar pemasaran dengan jaminan harga dasar melalui BUMD.

e. Pembangunan penyediaan irigasi dan Jalan Akses Agropolitan.

f. Percontohan / Show Window disetiap Kabupaten / Kota serta Posko Agropolitan.

g. Peningkatan SDM Pertanian.

h. Meningkatkan peran maize center dalam penelitian pengkajian teknologi serta penerapan teknologi baru.

i. Perencanaan dan koordinasi.

Dengan strategi diatas, hasil pembangunan pertanian khususnya angka produksi komoditi penghasil kalori utama masyarakat yaitu komoditi jagung mengalami peningkatan yang cukup signifikan.

Besarnya potensi komoditas jangung yang dimiliki provinsi Gorontalo tentunya menjadi suatu nilai tambah dan nilai jual yang dapat ditawarkan dalam kerjasama internasional. Mengingat posisi jangung sebagai bahan pangan yang menjanjikan di pasar internasional, pemerintah seharusnya mampu memanfaatkan peluang ini sebagai strategi dalam membuka pasar jangung dalam perdagangan internasional maupun menarik investasi asing.

\subsection{Pengembangan Industri Kreatif yang Signifikan}

Pertumbuhan ekonomi kreatif tentunya tidak bisa dilepaskan dari pertumbuhan ekonomi dan tingkat kesejahteraan masyarakat Provinsi Gorontalo itu sendiri. Semakin tinggi tinggi pertumbuhan ekonomi dan semakin baik tingkat kesejahteraan masyarakat tentunya akan mendorong munculnya semangat untuk melakukan usaha dan menghasilkan ide-ide kreatif yang 
dituangakan dalam produk-produk perdagangan. Di sisi lain pertumbuhan ekonomi kreatif akan berbanding lurus dengan kemajuan suatu daerah. Daerah yang semakin bergerak ke arah modernisasi akan akan semakin menstimulasi industri-industri kreatif. Masyarakat di daerah yang sudah beranjak modern akan lebih memfokuskan kegiatan ekonomi pada bidang industri dimana industri kreatif adalah bagian penting di dalamnya.Perusahaan merupakan motor penggerak perekonomian di suatu daerah. Jika ditinjau dari aspek perusahaan, jumlah perusahaan industri besar dan sedang di Provinsi ini sekitar 20 perusahaan, dengan tenaga kerja sebanyak 7.693 orang. Sedangkan Industri Mikro dan Kecil sebanyak 12.360 unit melibatkan 31.910 tenaga kerja dengan investasi berjumlah Rp. 132.942 .851 dan nilai produksi Rp. 510.021.820.

Adapun jika dilihat dari jenis barang dan jasa yang diperdagangkan, Jenis Industri Manufaktur Mikro dan Kecil di Provinsi Gorontalo adalah industri Makanan, industri Minuman, industri Tekstil, industri Pakaian Jadi, industri Kayu, Barang dari Kayu, Barang dari Kayu dan Gabus (tidak termasuk Furnitur) dan Barang Anyaman dari Bambu, Rotan dan Sejenisnya, industri Percetakan dan Reproduksi Media Rekaman, industri Farmasi, Produk Obat Kimia dan Obat Tradisional, industri Barang Galian Bukan Logam, industri Logam Dasar, industri Barang Logam, Bukan Mesin dan Peralatannya, industri Peralatan Listrik, industri Mesin dan Perlengkapan YTDL, industri Alat Angkutan Lainnya, industri Furnitur dan industri Pengolahan Lainnya.Pertumbuhan produksi Industri Manufaktur Mikro dan Kecil (IMK) Provinsi Gorontalo pada Triwulan I tahun 2016 (q-to-q) mengalami kenaikan sebesar 3,20 persen dibandingkan dengan Triwulan IV tahun 2015. Jenis industri yang mengalami kenaikan produksi tersebut adalah industri Makanan (3,10\%), industri Minuman $(2,14 \%)$, industri Tekstil (9,21\%), industri Pakaian Jadi (0,61\%), industri Kayu, Barang dari Kayu, Barang dari Kayu dan Gabus (tidak termasuk Furnitur) dan Barang Anyaman dari Bambu, Rotan dan Sejenisnya (5,85\%), industri Percetakan dan Reproduksi Media Rekaman (1,09\%), industri Barang Galian Bukan Logam (7,05\%), industri Alat Angkutan Lainnya (14,18\%) dan industri Furnitur (1,42\%). (BPS - 2016).

Di sisi lain majunya perekonomian suatu daerah dapat diukur dari tinggi rendahnya tingkat pengangguran. Jumlah angkatan kerja di Provinsi Gorontalo pada Agustus 2016 mencapai 562.196 orang, berkurang 1.206 orang dari keadaan Februari 2016 sebesar 563.402 orang. Pada Agustus 2016, jumlah penduduk yang bekerja sebagai buruh/karyawan sebesar 196.671 orang $(35,98$ persen), diikuti berusaha sendiri sejumlah 131.916 orang $(24,13$ persen), dan berusaha dibantu buruh tidak tetap/tidak dibayar sebanyak 87.761 orang (16,05 persen). (BPS - 2016).

Dari data ini dapat kita lihat bahwa penduduk Gorontalo yang bekerja dengan membentuk usaha sendiri berada diurutan kedua sebesar 24,13\%. Hal ini menunjukkan bahwa terdapat minat yang tinggi dalam mengembangkan usaha. Untuk itu adapun yang penting menjadi perhatian adalah bagaimana usaha tersebut dirancang sedemikian rupa sehingga mempunyai nilai ekonomis yang lebih tinggi. Salah satu diantanya adalah dengan memasukkan unsurunsur kreatifitas sehingga produk yang dihasilkan mempunya keunikan dan mampu bersaing dalam pasar. Dalam hal ini penting untuk memberikan pelatihan kewirausahaan kepada masyarakat sehingga produk-produk yang 
dihasilkan dapat lebih bernilai ekonomis. Di samping itu dorongan pemerintah juga secara langsung akan menjadi stimulus bagi masyarakat untuk menciptakan industri-industri kreatif yang baru.

Kota Gorontalo terus berkembang sebagai pusat perindustrian dan perdagangan. Industri kecil di Kota Gorontalo terbagi atas 2 (dua) kategori perusahaan industri dan industri kerajinan rumah tangga. Industri yang berkembang di Kota Gorontalo adalah industri makanan dan industri kerajinan dan pakaian jadi.Perusahaan perdagangan yang menonjol terdiri dari dari perusahaan terbatas, Firma $(\mathrm{CV})$, Koperasi dan perorangan. Selain itu juga terdapat pedagang besar, pedagang menengah dan pedagang kecil/mikro.

Namun jika melihat antusiasme masyarakat maka Kota Gorontalo mempunyai peluang yang paling besar dalam pengembangan industri kreatif terutama yang berbasis kuliner. Tidak dapat dipungkiri bahwa arus modernisasi Kota Gorontalo yang lebih pesat dibanding daerah-daerah lainnya di Provinsi Gorontalo sangat menstimulasi pola pikir masyarakat untuk mengembangkan industri kreatif. Kota Gorontalo telah berada dalam proses transformasi kota modern. Untuk itu Kota Gorontalo harus menyiapkan diri salah satunya dengan menyiapkan produk-produk dengan kreatifitas dan daya saing yang tinggi.

Salah satu contohnya adalah dengan mendesain sebuah acarayang digagas oleh Gorontalo Indie dengan mengundang penggiat pelaku-pelaku Industri kreatif lokal untuk bisa berpatisipasi dalam event ini. Menjadi event pertama yang memperkenalkan hasil Tangan kreatif dengan mengusung nama GULF (Gorontalo Urban Lot Festival). Kegiatan ini diproyeksikan menjadi event Rutin yang nantinya akan mengangkat Industri kreatif lokal. (Gorontalo Indie 2016).

Industri kreatif juga sudah berkembang dikalangan anak muda Kota Gorontalo. Hal ini dapat dilihat dari berbagai upaya yang dilakukan untuk mendukung kampanye industri kreatif. Salah satu jalan yang ditempuh adalah melalui media. Saat ini telah ada beberapa media online yang secara aktif mempromosikan industri kreatif. Beberapa diantaranya adalah www.gorontaloindie.comdan http://anamuda.com/. Di samping itu kalangan mahasiswa juga juga menggagas seminar Creative Preneur. Hal dilatarbelakangi dengan melihat kecenderungan kalangan muda Gorontalo masih sangat terpaku dengan pekerjaan sebagai PNS setelah menamatkan kuliah. Melalui seminar ini tentunya juga diharapkan dapat menumbuhkan semangat berbisnis kreatif dikalangan pemuda.

Dari gambaran umum di atas dapat kita lihat bahwa potensi yang dimiliki oleh Gorontalo memang sangat besar. Akan tapi pengolahan bahan baku menjadi produk yang berdaya jual tinggi memang belum maksimal. Untuk itu penting untuk mengenalkan konsep industri kreatif dikalangan masyarakat Gorontalo. Hal ini untuk lebih mendayakan UKM-UKM kreatif agar mempunyai nilai tambah yang besar. Dengan bergeraknya UKM kreatif maka tentunya akan mendorong perekonomian daerah.

\subsection{Provinsi Gorontalo Merupakan Provinsi yang Terus Berkembang dalam Pembangunan Ekonomi.}

Provinsi Gorontalo tentunya merupakan provinsi yang masih berumur sangat muda dibandingkan dengan provinsi lainnya di Indonesia. Sejak di tetapkannya provinsi Gorontalo sebagai daerah/provinsi pemekaran dari Sulawesi Utara yang dibentuk berdasarkan Undang Undang RI Nomor 38 Tahun 
2000, provinsi Gorontalo terus melakukan pembangunan dalam berbagai bidang dan lebih ditekankan pada pembangunan ekonominya.

Dalam konsep pembangunan sendiri pembangunan ekonomi seringkali didefinisikan sebagai suatu proses berdimensi jamak yang melibatkan perubahan-perubahan besar dalam struktur sosial, sikap masyarakat, dan kelembagaan nasional, seperti halnya percepatan pertumbuhan ekonomi, pengurangan ketidakmerataan, dan pemberantasan kemiskinan absolut. Provinsi Gorontalo meskipun berumur belum genap 10 tahun, tetapi prestasinya jauh lebih baik daripada daerah otonom lainnya yang lebih tua. Beberapa indikator keberhasilan pembangunan Provinsi Gorontolo sendri dapat dilihat dari peningkatan indeks pembangunan manusia (pada 2006 sebesar 68,98 menjadi 69,79 pada 2009), pertumbuhan ekonomi (pada 2006 sebesar 7,06 \% menjadi $7,63 \%$ pada 2009), serta penurunan angka kemiskinan hingga $23,19 \%$ pada 2010. (BPS Prov Gorontalo).

Mewujudkan masyrakat yang kritis dan mengerti akan partisipasinya dalam pembangunan, tak bisa dilepaskan dengan upaya pemberdayaan yang dilakukan oleh pemerintah daerah, karena sebagaimana diketahui dalam prioritas pemerataan pembangunan di suatu daerah, kebijakan pembangunannya diadakan pada peran serta masyarakat sebagai penggerak penyelenggaraan pemerintah daerah yang merupakan pengejawantahan dari pembangunan dari rakyat oleh rakyat dan demi kemakmuran serta kesejahteran rakyat.

Adapun pokok-pokok dan strategi pemberdayaan masyarakat yang bisa dikembangakan di berbagai daerah antara lain : Pertama, penanggulangan kemiskinan, dimana perlu peran serta masyarakat dalam bentuk kemitraan yang berwawasan kebangsaan. Kedua, penajaman program yang diarahkan untuk peningkatan kegiatan yang berorientasi pada perbaikan ekonomi serta kesejahteraan rakyat. Ketiga, memecahkan keterbelakangan dan peningkatan kapasitas masyarakat untuk maju, mandiri serta sejahtera. Sasaran dari semua itu adalah ekonomi, masyaraakat dan peningkatan pendapatan agar masyarakat miskin bias turun jumlahnya.

Dalam perjalanannya selama beberapa tahun semenjak pisah dari provinsi Sulut, pemerintah provinsi Gorontalo boleh di bilang sangat konsisten dalam masalah mengentaskan kemiskinan. Lihat saja dari data yang dikeluarkan Bappeda provinsi Gorontalo, dimana pada awalnya jumlah kemiskinan yang dimiliki oleh provinsi Gorontalo adalah sebesar $72 \%$ dari 848 ribu jumlah penduduk Gorontalo sejak pisah dari provinsi Sulut. Kini angka tersebut mulai menyusut seiring dengan majudan berkembangnya program pemerintah khususnya di sektor pertanian dengan entry point jagung serta perikanan. Berdasarkan survei pada Maret 2017 persentase penduduk miskin di Provinsi Gorontalo hanya tinggal sebesar 17,65 persen (BPS Prov. Gorontalo).

Provinsi Gorontalo adalah salah satu dari hanya sedikit daerah pemekaran dengan geliat pembangunan yang sangat dinamis. Data indikator makro memperlihatkan trend kenaikan yang cukup signifikan dari tahun ke tahun. Dari sisi perkembangan sektor riil, indikator pertumbuhan ekonomi Gorontalo, dalam rentang waktu 8 tahun sejak pemekaran berada di atas rata-rata nasional; dengan pertumbuhan rata di atas $5 \%$, dan/atau rata-rata di atas pertumbuhan nasional. Pertumbuhan ekonomi Gorontalo tercatat sebagai pertumbuhan ekonomi tertinggi kedua di regio Sulawesi pada tahun 2004 
setelah Sulawesi Tenggara. Berkaitan dengan data perkembangan daerah di atas, provinsi Gorontalo telah dapat dikatakan mampu melakukan pembangunan daerah dengan sangat baik. Provinsi Gorontalo telah mampu melakukan perubahan-perubahan besar dalam percepatan pertumbuhan ekonomi yang menjadi salah satu kriteria keberhasilan daerah atau provinsi dalam melakukan pembangunan.

Melihat prospek kedepan, kinerja perekonomian Gorontalo untuk keseluruhan tahun 2017 diperkirakan meningkat dibandingkan tahun 2016 dengan tingkat pertumbuhan pada kisaran 6,4\%-6,8\%. Sumber utama peningkatan pertumbuhan ekonomi pada tahun 2017 berasal dari masih kuatnya permintaan domestik dan perbaikan ekspor. Walaupun adanya risiko terkait keterbatasan anggaran pemerintah, khususnya transfer dana (dana desa dan DAU) dan terbatasnya belanja modal Pemerintah Provinsi akibat adanya pengalihan alokasi anggaran gaji guru di Provinsi Gorontalo. Sementara itu, tingkat inflasi pada tahun 2017 diperkirakan cenderung sedikit meningkat dibandingkan tahun 2016 dengan rentang dalam kisaran target inflasi nasional sebesar $4 \% \pm 1 \%$ (yoy). Berbagai risiko peningkatan tekanan inflasi yang bersumber pada kebijakan pemerintah, harus diredam dengan pengendalian inflasi pada kelompok volatile food melalui kegiatan peningkatan produksi dan pengendalian harga melalui TPID (Bank Indoneisia, 2017).

Semua pihak telah sepakat bahwa kerjasama antar daerah perlu dikembangkan karena berbagai manfaat yang ditawarkan. Namun demikian, kerjasama antar daerah antar negara khususnya dalam konteks Selatan-Selatan merupakan sesuatu yang baru. Oleh karena itu, selain menyediakan peluang juga dihadapkan pada berbagai tantangan. Beberapa tantangan yang dapat diidentifikasi bersumber dari lemahnya faktor kelembagaan sebagai berikut:

\section{Tradisi Kerjasama}

Kerjasama antar daerah antar negara yang berpola networking didasarkan pada inter-relasi yang dilakukan oleh daerah yang bersifat bebas dan mandiri dalam berhubungan dengan daerah lain. Dalam pola networking tidak ada struktur kewenangan sentral. Semua tujuan dihasilkan dari kesepakatan dari semua anggota yang tergabung dalam forum kerjasama antar daerah sebagai perwujudan aksi bersama (collective action). Namun demikian, norma kerjasama menjadi faktor penentu terbentuknya kerjasama daerah. Tradisi kerjasama dapat dipercepat melalui kepemimpinan para pengambil kebijakan. Persoalannya, kepemimpinan publik yang berorientasi terbuka dan peka terhadap perubahan lingkungan seringkali sulit ditemukan di dalam birokrasi pemerintahan daerah. Banyak diantara mereka merasakan kenyamanan tanpa memandang perlu adanya perubahan. Mereka terjebak dalam tugas-tugas rutin administratif dan mengandalkan petunjuk atasan. Ketiadaan aturan teknis pelaksanaan semakin memberikan dampak terhadap rendahnya pengambilan risiko di kalangan pejabat birokrasi.

\section{Dukungan Kelembagaan}

Berkaca dari kerjasama antar daerah di wilayah Barlingmacakeb, aturan kelembagaan seringkali dianggap tidak melindungi kerjasama antar daerah yang telah berlangsung. Dalam hal ini, pemerintah daerah yang melakukan kerjasama dihadapkan pada persoalan ketidakjelasan aturan pengelolaan keuangan. Aturan-aturan teknis kerjasama daerah (PP No. 58/2005, 
Permendagri No. 13/2006, Permendagri No. 59/2007) yang ditetapkan Pusat belum menyentuh penggunaan keuangan dan aset yang dikelola oleh pemerintah daerah yang bekerjasama. Situasi problematik ini menempatkan daerah pada persoalan akuntabilitas pengelolaan keuangan dan keraguan untuk melanjutkan kesepakatan kerjasama. Akibatnya, model regional management yang sudah dirintis sejak tahun 2004 terancam bubar. Apabila di tingkat nasional saja kerjasama antar daerah masih menemui persoalan kelembagaan, maka kerjasama antar daerah antar negara kemungkinan besar juga akan menghadapi persoalan kelembagaan yang sama.

\section{Dukungan Pendanaan}

Meskipun tersedia peluang dana dari donor, namun demikian tidak semua daerah dapat mengakses atau mereplikasi praktik baik yang ditunjukkan oleh Gorontalo. Keterbatasan anggaran untuk penjajakan kerjasama di level internal akan membuat pemerintah daerah untuk berpikir untuk menundanya. Hal ini tidak lepas dari besarnya komponen belanja pegawai yang menyedot anggaran pendapatan dan belaja daerah. Besarnya komponen biaya tidak langsung dalam APBD membuat daerah tidak memiliki anggaran yang cukup untuk menginisiasi kerjasama antar daerah antar negara.

\section{Egoisme Daerah}

Kerjasama antar daerah antar negara bisa saja terkendala oleh dukungan yang rendah dari pemerintah kabupaten/kota. Apalagi jika kabupaten/kota sendiri tengah mengembangkan kerjasama daerah diantara mereka, maka pelibatan kerjasama yang diinisiasi oleh pemerintah provinsi mungkin saja tidak mendapatkan dukungan. Kajian yang dilakukan oleh LAN menemukan bahwa kabupaten/kota menilai pemerintah provinsi tidak optimal bahkan tidak banyak peran yang dilakukan. Jika kemudian tiba-tiba pemerintah provinsi melibatkan kerjasama daerah dalam program kerjasama antar daerah antar negara yang dipimpin oleh pemerintah provinisi, maka tidak mudah untuk melibatkan kabupaten/kota sebagai bagian dari kerjasama tersebut.

\section{PENUTUP}

Internasionalisasi daerah melalui model kerjasama internasional pada kenyataannya menawarkan prospek yang cerah. Perubahan paradigma administrasi negara dari birokrasi tradisional ke arah pasca birokrasi telah membawa pengaruh mengenai pola kerjasama yang semakin luas dan melibatkan aktor-aktor eksternal. Berbagai peluang tersedia dari pengembangan kerjasama internasional seperti: pertukaran sumber daya, bantuan teknis, dan teknologi, fasilitas pendanaan, dan pengembangan jejaring kerjasama untuk akselerasi pembangunan. Namun demikian, berbagai tantagan kelembagaan perlu segera direspon oleh pemerintah daerah maupun pusat melalui penguatan kepemimpinan gubernur dan kapasitas pemerintah provinsi, penyediaan aturan hukum dan teknis pelaksanaan yang jelas serta pendanaan yang memadai.

\section{DAFTAR PUSTAKA}

Arfani, Riza Noer \& Gebyar Lintang Ndadari (eds). Kota dan Globalisasi : Menuju Yogyakarta Kreatif. Yogyakarta: Institute of International Studies. 2012. 
Berita Resmi Statistik - Badan Pusat Statistik Provinsi Gorontalo - No. 62/11/75/Th.X, 7 November 2016 - PERTUMBUHAN EKONOMI GORONTALO TRIWULAN III-2016.

Berita Resmi Statistik - Badan Pusat Statistik Provinsi Gorontalo No. 26/05/75/Th.IX, 2 Mei 2016 - PERTUMBUHAN PRODUKSI INDUSTRI MANUFAKTUR MIKRO DAN KECIL (IMK) \& INDUSTRI MANUFAKTUR BESAR DAN SEDANG (IBS) PROVINSI GORONTALO TRIWULAN I TAHUN 2016.

Berita Resmi Statistik - Badan Pusat Statistik Provinsi Gorontalo No. 50/09/75/Th.X, 1 September 2016 - PERKEMBANGAN EKSPOR DAN IMPOR PROVINSI GORONTALO JULI 2016.

Berita Resmi Statistik - Badan Pusat Statistik Provinsi Gorontalo No. 64/11/75/Th.X, 7 November 2016 - KEADAAN KETENAGAKERJAAN PROVINSI GORONTALO AGUSTUS 2016.

Bank Indonesia, Kajian Ekonomi dan Keuangan Regional Provinsi Gorontalo Februari 2017, diakses melalui http://www.bi.go.id/id/publikasi/kajianekonomi-regional/gorontalo/Pages/Kajian-Ekonomi-dan-KeuanganRegional-Provinsi-Gorontalo-Februari-2017.aspx pada 4 Mei 2017.

BadanPusat Statistik Provinsi Gorontalo, Berita Resmi Statistik No. 37/07/75/Th.X. 17 Juli 2017, Kondisi Kemiskinan Provinsi Gorontalo Maret 2017.

BPS Provinsi Gorontalo, Indeks Pembangunan Manusia Menurut Kabupaten/Kota di Gorontalo, 2010-2016, diskses melalui https://gorontalo.bps.go.id/linkTableDinamis/view/id/57 pada 4 Mei 2017.

Clark, Greg \& Tim Moonen, Open Cities Thematic Paper - Internasionalisation, URBACT.

Departemen Perdagangan Republik Indonesia. "Peta Jalan Pengembangan Ekonomi Kreatif." Penguatan Pilar dan Landasan 2009-2015. 2008.

Kaarbo, Juliet, Jeffrey S. Lantis, Ryan K. Beasley, "The Analysis of Foreign Policy ini Comparative Perspective."

Peraturan Menteri Dalam Negeri Nomor 3 Tahun 2008 Tentang Pedoman Pelaksanaan Kerjasama Pemerintah Daerah Dengan Pihak Luar Negeri.

Potensi Provinsi Gorontalo, diakses melalui https://www.gorontaloprov.go.id/potensi/pertanian pada 5 November 2016.

Renstra Badan Ketahanan Pangan dan Pusat Informasi Jagung Provinsi Gorontalo Tahun 2013-2017. 